\title{
Textual Development within Paradigms and Paradigm Shifts
}

\section{Pakkala, Juha Kalevi}

2014

Pakkala , J K 2014 , ' Textual Development within Paradigms and Paradigm Shifts ' , Hebrew pÿBible and Ancient Israel , vol. 3 , no. 3 , pp. 327342 . https://doi.org/10.1628/219222714X14115480974934

http://hdl.handle.net/10138/328818

https://doi.org/10.1628/219222714X14115480974934

publishedVersion

Downloaded from Helda, University of Helsinki institutional repository.

This is an electronic reprint of the original article.

This reprint may differ from the original in pagination and typographic detail.

Please cite the original version. 


\section{Juha Pakkala}

\section{Textual Development within Paradigms and Paradigm Shifts}

It is evident that the Hebrew Bible was continually edited by successive later hands. Although there are some dissenting voices, this is implied by the differences seen in documented evidence. Although part of this evidence supports the conventional redaction-critical assumption that texts were almost exclusively expanded (e.g., MT / LXX Jeremiah, the Samaritan Pentateuch), some documented evidence implies that more radical techniques were used, including rewriting, relocation, and omission. Both types of evidence have to be included in any model that seeks to understand how the texts were edited.

The dichotomy of evidence and alternation between conservative transmission and more radical phases of transmission may be perceived from the perspective of paradigms and paradigm shifts. The conservative transmission by expansions took place within the same ideological paradigm, while radical editorial techniques are probable in paradigm shifts. Recognition that the development of the Hebrew Bible took place within both paradigms and paradigm shifts has potentially considerable consequences for redaction criticism.

\section{Introduction}

The Hebrew Bible was continually edited by successive later hands. This is implied by documented evidence by which I refer to differences between the preserved versions or translations, manuscript evidence from Qumran, and other parallel texts where the diachronic development of the Hebrew scriptures can be observed. In view of this evidence, it would be difficult to deny that redactors, editors, or scribes responsible for the transmission of the texts made successive editorial changes ${ }^{1}$ to all texts of the Hebrew scriptures before they were frozen as too holy to be changed sometime in the Common Era. Although most of the documented evidence reflects a relatively late stage in the development of the Hebrew scriptures, it is reasonable to assume

1 In this paper 'editorial changes' broadly refer to various types of changes that were made to the texts. 
that similar processes of editing also took place in the earlier stages of textual development that are not witnessed by documented evidence. Many texts in the Hebrew scriptures may have developed in a complicated process lasting centuries before the text was stabilized. ${ }^{2}$

According to the conventional assumption in biblical studies, the texts of the Hebrew Bible ${ }^{3}$ were mainly or exclusively expanded in their transmission. ${ }^{4}$ This assumption is crucial in redaction criticism, which seeks to reconstruct the different literary strata, and thus many representatives of this methodology have excluded the possibility that parts of the older text could have been omitted in transmission. ${ }^{5}$ The reconstruction of a sequence of successive redactions has largely been built on the assumption that all strata are preserved in the "final" versions of the texts. Accordingly, when the later additions are peeled off, the older layer of any analyzed text should emerge as a coherent one. If, however, the older text appears fragmentary, the analysis is assumed to have failed (this is the so-called Gegenprobe). ${ }^{6}$ The main reason for always preserving the older text would have been the assumed authoritativeness or divine origin of the Hebrew Bible. The editors or redactors would have avoided omitting any part of what was regarded as God's Word or otherwise holy and authoritative. ${ }^{7}$

The assumption that nothing was omitted is probably invalid. To be sure, there is documented evidence that supports the idea of almost exclusive

2 In some cases, the text was never fully stabilized. For example, three considerably different versions of Esther and Daniel remained in circulation and were eventually adopted in different traditions. As other analogous examples one could mention Jeremiah, Samuel, Judges, and Ezra-Nehemiah.

3 One commonly refers to the Hebrew Bible, but in view of the increasingly significant evidence from early Hebrew texts that were eventually left out of the Hebrew Bible, one should not limit the perspective to the Hebrew Bible alone. Consequently, I will refer to the Hebrew scriptures in this paper, unless the Hebrew Bible is specifically meant.

4 Unintentional omissions, such as those that were caused by homoioteleuton or homoioarchton, are generally acknowledged in research, while intentional omissions are generally rejected especially in literary and redaction criticism.

5 For example, O.H. Steck, Exegese des Alten Testaments: Leitfaden der Methodik (12 $2^{\text {th }}$ ed.; Neukirchen: Neukirchener Verlag, 1989), 46; R. G. Kratz, "Redaktionsgeschichte/ Redaktionskritik I Altes Testament," in TRE 28 (1997): 367-378, here p. 370; C. Levin, The Old Testament: A Brief Introduction (Princeton: Princeton University Press, 2005), 26-27; U. Becker, Exegese des Alten Testaments (UTB 2664; Mohr Siebeck, 2005), 84; J.-L. Ska, Introduction to Reading the Pentateuch (Winona Lake: Eisenbrauns, 2006), 169-170.

6 See, for example, L. Schmidt, "Literarkritik I Altes Testament," TRE 21 (1991): 211-222; and S. Kreuzer et al., Proseminar I Altes Testament: Ein Arbeitsbuch (Stuttgart: Kohlhammer, 1999), 60.

7 Thus, for example, Ska, Introduction, 169-170, 182-183; Levin, The Old Testament, 22, 26-27; Becker, Exegese des Alten Testaments, 84. 
expansion. As a prime example, one should mention the Masoretic text of Jeremiah in comparison with the Greek text, which generally reflects an earlier stage in the development of this book. ${ }^{8}$ After the two textual traditions diverged and developed independently, the Hebrew text was extensively expanded. While additions are met throughout the text, more radical editorial changes, such as omissions and replacements, are rare exceptions, unintentional corruptions, and/or controversial cases. The Samaritan Pentateuch portrays a similar picture of the editorial process. In comparison with the Masoretic version, which generally reflects an earlier stage of the text, the Samaritan version contains repeated expansions. Omissions are again minor, accidental, and/ or controversial cases. It appears that in these cases, both of which contain a significant text-mass for investigation, the later editors avoided leaving out parts of the older text through replacement, rewriting, or by full omission. The documented evidence from Jeremiah and the Samaritan Pentateuch thus may give the impression that the idea of almost exclusive expansion stands on solid ground. However, they only provide a partial picture.

There is documented evidence that implies the use of more radical editorial techniques in the transmission of the Hebrew scriptures: parts of the transmitted texts could also have been rewritten, relocated, and omitted. ${ }^{9}$ As evidence for this, one could mention, for example, the use of Kings in Chronicles, the Covenant Code in Deuteronomy, an older version of EzraNehemiah in First Esdras, a Hebrew version of Esther in the two Greek versions, and the Temple Scroll in relation to the Pentateuch. All these texts contain examples of various radical techniques in relation to the source text that represents the earlier stage in the development of the text. ${ }^{10}$ For the investigation of the prehistory of any given text, it is not crucial whether the new text was or eventually became a different literary work than the source text. When investigating the diachronic development of the Hebrew scriptures, all evidence that shows how the older text was used should be taken into consideration. The undocumented early stages in the history of texts are unknown and thus it is quite possible, even probable, that some of their edi-

8 This does not exclude the possibility that, in some cases, the Hebrew text could preserve a more original reading. The relationship between the MT and the LXX of Jeremiah is debated, but it seems more probable that the LXX generally preserves the older text.

9 In this paper, radical mainly refers to the radical techniques of editing, according to which parts of the older text could be omitted. In some cases, conservative techniques where the older text is preserved may occasion radically altered meaning of the older text.

10 For examples, see J. Pakkala, God's Word Omitted (FRLANT 251; Göttingen: Vandenhoeck \& Ruprecht, 2013). 
torial stages are analogous to the ones mentioned above. In other words, our perspective to investigate the texts is necessarily from the "final" texts. When we seek to understand how the texts were edited and what happened to them beyond the documented evidence, one also needs to take into consideration the possibility that some of the literary stages may have related to the older text in a similar way as Chronicles relates to Kings, ${ }^{11}$ First Esdras to EzraNehemiah, Deuteronomy to the Covenant Code, or the Temple Scroll to the Pentateuch. In other words, it is not inevitable that, in the entire prehistory of texts which redaction criticism seeks to investigate, all scribes used only techniques that we can observe in the documented evidence of Jeremiah and the Samaritan Pentateuch.

Examples where the older text was challenged by radical revisions are not restricted to the evidence provided by a comparison of different texts that eventually were regarded as different compositions. There is text-critical evidence, especially from the books of Samuel and Kings, that implies censoring by omitting theologically offensive sections. ${ }^{12}$ For example, a section of 2 Kgs 10:23-24 was left out by a later editor because it implies that Baal and Yahweh were worshipped side by side in Baal's temple. Such a conception would have been incomprehensible in Second Temple times and was thus a potential object of radical intervention. The older text is found in some Greek manuscripts and Old Latin witnesses, while the Masoretic text contains a censored version. ${ }^{13}$

LXX: ${ }^{14}$

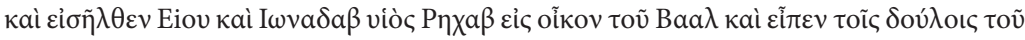

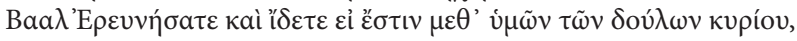

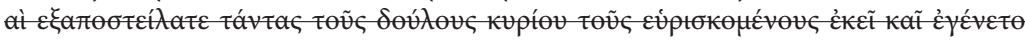

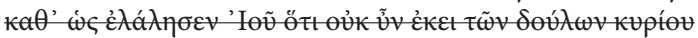

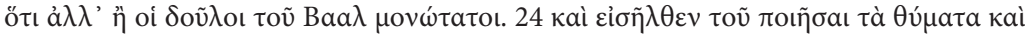

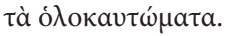

11 The relationship between Chronicles and Samuel may be more complicated, since it is not certain that the Chronicler used Samuel directly.

12 For additional similar examples, see Pakkala, God's Word Omitted.

13 For details and further discussion of the evidence, see J. Trebolle Barrera, Jehú y Joás: Texto y composición literaria de 2 Reyes 9-11 (Institución San Jerónimo 17; Valencia: 1984), 147-157, 222-223.

14 Cf. also Codex Vindobona: "Et intrauit ieu rex israel et ionadab filius recab in templum bahal et dixit ieu ad seruos bahal scrutinate et uidetene sit uobiscum ex seruis domini et eicite omnes seruos domini qui inuenti fuerint in templum bahal. Et factum est sicut locutus est ieu rex et cum nemo fuisset ibi de seruis domini nisi soli bahal. ${ }^{24}$ Et introierunt eu faceret sacrificia et holocausta ..." 
And Jehu and Jonadab the son of Recab entered the temple of Baal. And he (Jehu) said to the worshippers of Baal, "Search and see that there are no worshippers of Yhwh with you and bring out all worshippers of Yhwh who have been found in the temple of Baal. And it came to pass as Jehu the king had spoken, and there were no (more) of the worshippers of Yhwh,

but only worshippers of Baal." 24 And they went to offer sacrifices and burnt offerings ...

MT:

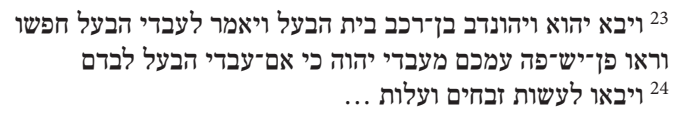

${ }^{23}$ And Jehu entered the temple of Baal with Jehonadab son of Rechab; And he said to the worshipers of Baal, "Search and see that there are no worshippers of Yhwh with you, but only worshipers of Baal." ${ }^{24}$ And they went to offer sacrifices and burnt offerings ...

Similar examples - mostly less extensive than 2 Kgs 10:23-24 yet often equally significant - can be found in many other parts of Samuel and Kings. ${ }^{15}$

Despite its abundance, the theories on editing, especially in redaction criticism, have not been firmly anchored to documented evidence. Especially the evidence for radical editorial techniques - much of which has been readily available since early research (e.g., Chronicles, First Esdras, text critical evidence provided by the comparison between the MT and the LXX) - has often been neglected in theories on editing. Instead of assuming only conservative techniques of transmission, all the evidence should be included in any model or theory of the editorial processes of the Hebrew scriptures. Otherwise one risks building a methodology that may be easier to implement but that automatically fails to recognize factual changes since they have been rejected from the start.

The evidence points in two different directions as far as the techniques of editing are concerned. Part of the evidence implies a rather conservative technique where practically everything was preserved by later transmitters. This practice seems to have been the usual one when the texts were edited, and it may also be the reason why many scholars have concluded that nothing was omitted during the transmission. On the other hand, there is enough evidence for radical techniques of editing that it would not be justified to ignore them in any model or theory on editing.

To explain the dichotomy of evidence, it is improbable that the conservative and radical techniques of transmissions alternated randomly. It is also unlikely that there was a linear development from freedom to constrained

15 See Pakkala, God's Word Omitted, 183-252. 
development. Undoubtedly, one can see gradually increasing reluctance to alter the older texts, which eventually become unchangeable, but there are many examples of radical techniques being employed after more conservative stages of transmission. The documented evidence suggests that in the long-term development of any text, the probability is high that stages of transmission that mainly use conservative techniques are interrupted at some point by more radical editorial processes. As an example, one could take the development of the Passover law, for which six different versions are preserved for comparison. ${ }^{16}$ It is apparent that these versions reflect different stages in the transmission of the law. ${ }^{17}$

16 For other examples, see Pakkala, God's Word Omitted.

17 Thus most scholars, such as B. M. Levinson, Deuteronomy and the Hermeneutics of Legal Innovation (Oxford: Oxford University Press, 1997), 53-97. Thus also many others, for example, T. Veijola, Das 5. Buch Mose: Deuteronomium. Kapitel 1,1-16:17 (ATD 8,1; Göttingen: Vandenhoeck \& Ruprecht, 2004), 328-329, who assume that Deut 16:1-8 is dependent on Exod 23:15, 18. The relationship between the Holiness Code and the (probably) older law codes is a complicated issue. Many scholars since B. Baentsch, Das Heiligkeits-Gesetz Lev XVII-XXVI (Erfurt: Hugo Günther, 1893), 76-80, have argued that the author of the Holiness Code used Deuteronomy as well as the Covenant Code; see, for example, A. Cholewinski, Heiligkeitsgesetz und Deuteronomium: Eine vergleichende Studie (AnBib 66; Pontificio Istituto Biblico: Rome, 1976); K. Grünwaldt, Das Heiligkeitsgesetz Leviticus 17-26: Ursprüngliche Gestalt, Tradition und Theologie (BZAW 271; Berlin and New York: de Gruyter, 1999), 376; C. Nihan, "The Holiness Code between D and P: Some Comments on the Function and Significance of Leviticus 17-26 in the Composition of the Pentateuch," in Das Deuteronomium zwischen Pentateuch und Deuteronomistischem Geschichtswerk (ed. E. Otto and R. Achenbach; FRLANT 206; Göttingen: Vandenhoeck \& Ruprecht, 2004), 81-122, here pp. 82-98. However, the issue has not been resolved; for other solutions. See G. Braulik, "Weitere Beobachtungen zur Beziehung zwischen dem Heiligkeitsgesetz und Deuteronominium 19-25," in Das Deuteronomium und seine Querbeziehungen (ed. T. Veijola; PFES 62; Göttingen: Vandenhoeck \& Ruprecht, 1996), 23-55, esp. pp. 50-52; and H. Reventlow, Das Heiligkeitsgesetz formgeschichtlich untersucht (WMANT 6; Neukirchen: Neukirchener Verlag, 1961). As for the relationship between Leviticus 23 and Numbers 28 , it has been argued since early research that Numbers 28-29 is a younger version in comparison with Leviticus 23. Thus, for example, B. Baentsch, Exodus, Leviticus, Numeri (HKAT 1.2; Göttingen: Vandenhoeck \& Ruprecht, 1903), 640; H. Holzinger, Numeri (KHAT 4; Tübingen: Mohr [Siebeck] 1903), 140-141, 143; and C. Steuernagel, Lehrbuch der einleitung in das Alte Testament: mit einem anhang über die apokryphen und pseudepigraphen (Tübingen: Mohr Siebeck, 1912), 168-169. On the relationship between the Passover law in the Temple Scroll and the Pentateuch, see M.M. Zahn, Rethinking Rewritten Scripture: Composition and Exegesis in the 4QReworked Pentateuch Manuscripts (STDJ 95; Leiden: Brill, 2011), 198-204. Nevertheless, according to her, the author of T 17:6-16 mainly used Lev 23:5-8, but since T 17:6-16 includes a parallel to the plus in Num 28:16-25 (in comparison with Lev 23:5-8), the author of the Temple Scroll may have primarily used Num 28:16-25 in the Passover law. For further discussion on the relationship between the passages, see Pakkala, God's Word Omitted. 


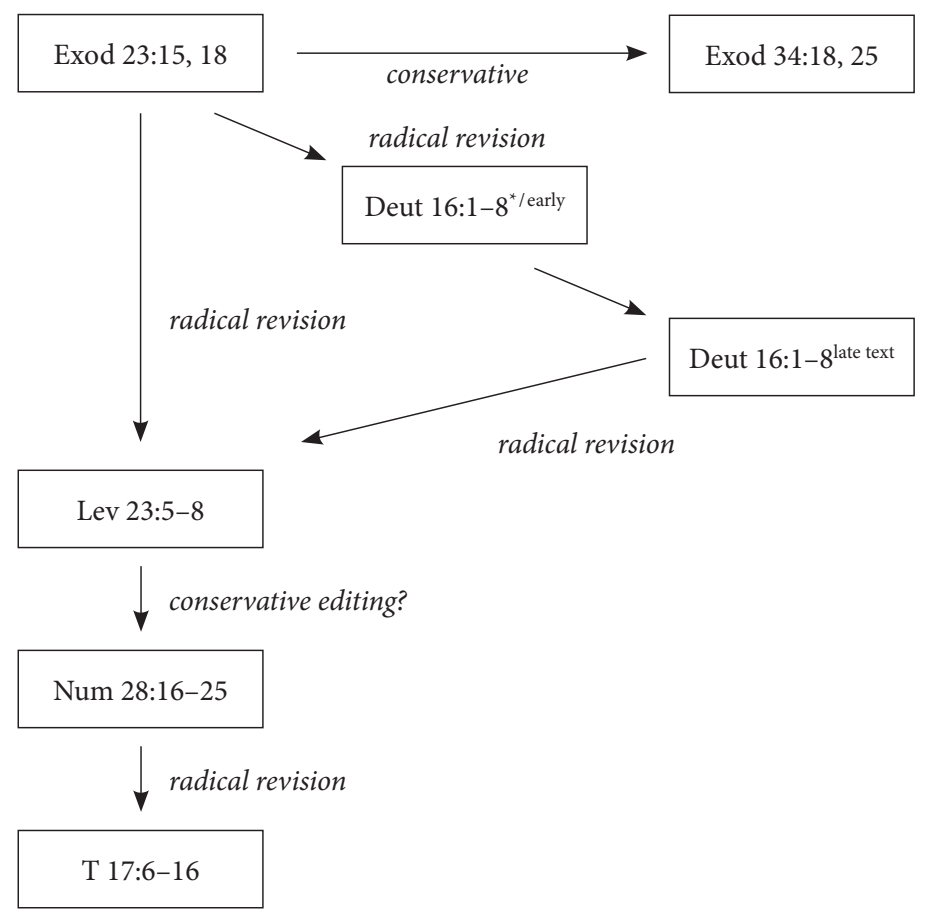

It is apparent in this case that the text was transmitted using mainly conservative techniques in an earlier stage (for example, from Lev 23:5-8 to Num 28:16-25 as the latter preserves nearly every letter of the older law, merely making a large expansion in vv. 19-24), while a revision using more radical techniques took place at a later stage when the author of $\mathrm{T}$ 17:6-16 used Num 28:16-25 as the source text. The development of the Passover law, as can be observed in the six preserved versions, seems to have alternated between conservative and radical revisions of the older text. Although the preserved versions only provide us with glimpses of the certainly more complicated development, texts for which we do not possess documented evidence may have had an analogous prehistory that utilized both conservative and radical editorial techniques.

\section{Paradigms and Paradigm Shifts}

The alternation between conservative and radical editorial processes may be perceived from the perspective of paradigms and paradigm shifts. An ideo- 
logical ${ }^{18}$ paradigm ${ }^{19}$ tended to transmit the texts by using conservative techniques, while paradigm shifts often allowed radical techniques of editing to be used. Although one should not make a rigid rule that this was always and strictly the case, this perspective provides an explanation for what otherwise would seem a rather haphazard alternation between the two different processes in the transmission of the same textual line.

Within an ideological paradigm, a social group perceives and interprets reality through certain shared conceptions. A text-transmitting community would be no exception, and here one may refer to an ideological group or movement, scribal school, or any context that transmitted any given text. A paradigm implies a stable environment to preserve its ideological continuity, and groups that were part of an ideological paradigm would seek to preserve it. Since central texts often upheld and legitimized the paradigm and its order, the transmitting community would have no interest in challenging such texts by omitting or replacing parts of them. Quite the contrary, there would be considerable resistance to challenging the older text by radical changes. This is especially true for authoritative texts that functioned as an interpretative lens through which developments and changes in the environment would have been perceived. As long as they are gradual and limited, the changes in socio-historical environment would have been interpreted through the older conceptions provided by authoritative texts. At the same time, the changes in the environment would have necessitated adjustments in the texts - otherwise the texts would have risked becoming outdated - but in order to preserve continuity and stability, this would mainly take place in the form of expansions. Challenging the older text would have meant rocking the boat, and therefore conservative editorial techniques would be the natural consequence of a transmission within an ideological paradigm.

Sometimes the changes in the environment of transmission were significant. Catastrophic events in particular would have unsettled the social order and its main institutions. There could be a catastrophic political event, an economic disaster, the loss of a land, state, or monarchy, destruction or rebuilding of a temple, the destruction of an important cult item, pivotal religious schism, or something else that decisively altered the ideological

18 One could also refer to a social paradigm, but since we are dealing with authoritative texts, I seek to emphasize the conceptual aspect of the paradigm.

19 It would also be possible to use the word worldview. Paradigm and paradigm shift are often used to refer to certain basic assumptions in natural sciences; see T.S. Kuhn, The Structure of Scientific Revolutions (Chicago: University of Chicago Press, 1996³). However, these concepts have since been used in social sciences as well, and their use has been expanded to comprise various meanings and contexts. 
environment. ${ }^{20}$ Often the reasons are external, but a serious religious schism, for example, could also cause a change in the environment of a text. A group that split off from the main group would take up the authoritative texts of the tradition, but because of the schism, the ideological paradigm or the horizon of interpreting reality may have changed, which would potentially cause a reevaluation and radical revision of the texts. ${ }^{21} \mathrm{~A}$ paradigm shift may involve an entire community or it may only apply to a small group, who, for example, split off from the main group. Here it needs to be stressed that several parallel (and perhaps also contradictory) ideological paradigms were probably the rule in ancient Judaism rather than the exception. This is implied by the existence of conceptually very different texts that eventually formed the Hebrew Bible, as well as the existence of many Jewish parties with diverse conceptions in the Second Temple period.

Despite resistance to change, as in any existing order, too great a contradiction with the experienced reality would eventually necessitate a radical revision of the texts. While stable conditions deal with the evident changes in the environment by making expansions, a sudden and substantial change in the socio-historical environment, causing an ideological paradigm shift, would have to be resolved by more radical processes. Otherwise, the texts would be in danger of becoming irrelevant and being replaced by others that are more suited to the new context. In other words, it is probable that a radical revision of a text becomes more likely when its socio-historical environment of transmission is suddenly and substantially changed.

Taking concrete examples, the ideological paradigm during the monarchy had been essentially dependent on the temple and kingship, and during this time there most probably existed a set of authoritative religious texts that were closely connected to these institutions. When the institutions were destroyed in 586 B.C.E., the existing ideological paradigm collapsed, ${ }^{22}$

20 Many such events can be found in the history of Judah, Israel, and Judaism: The destruction of the Northern Kingdom in 722 B.C.E., the destruction of Judah in 586 B.C.E., the destruction of Yahweh's cult statue in 586 B.C.E., the rebuilding of the temple sometime in the $5-4^{\text {th }}$ centuries B.C.E., the rise and fall of the Hasmonean dynasty/ kingdom in 140 and 116 B.C.E. respectively, the destruction of the Second Temple in 70 C.E. In addition to such major political events, many others certainly took place that have not left clear traces in the records.

21 It is possible that the beginning of the different Jewish parties of the Second Temple period goes back to a religious schism that had long-lasting effect on the communities in question. A religious schism that results in sectarian groups emerging would represent a paradigm shift. For example, some Qumranic texts imply a confrontation between the community and that of the temple priests in Jerusalem.

22 Although not universally accepted, the dichotomy between the religious situations 
and the old authoritative texts would not have provided any meaningful explanation in the new situation. Most of them became irrelevant, outdated, and were eventually forgotten. There are fragments of some of these texts scattered around the Hebrew scriptures. For example, the ideology of Yahweh as the storm or solar god was certainly reflected in many older texts of ancient Judah and Israel (cf. Ugarit), but only a fraction of them are preserved, embedded in new contexts in some psalms and elsewhere. ${ }^{23}$ As a consequence of 586 B.C.E., completely revised authoritative texts, based on the new contexts faced by the Israelites, had to emerge. Instead of relying on the (divine) monarchy and the temple cult, the new paradigm(s) had to be built on different conceptions. ${ }^{24}$ Because central institutions - monarchy, state, and temple - were destroyed in 586 B.C.E., it is likely that the Hebrew scriptures are, for the most part, post-586 B.C.E. products.

This is the case with Deuteronomy. Although some of the laws in the book probably originated in monarchic times, they are now part of a book that essentially depends on an entirely new ideological context. The laws have also often been edited to fit their new context. It is thus not surprising that the main institutions of the monarchic period are almost completely missing in Deuteronomy. ${ }^{25}$ Because of the new situation without the temple and king, the texts had to be thoroughly revised to be relevant. Instead of the temple, the law became the center of the religion, while the king was replaced by Moses as the mediator between the divine and Israel. ${ }^{26}$

before and after the destruction of 586 B.C.E. has been assumed by many scholars since early research.

23 There is clear evidence of solar aspects in Yahweh's character. See, for example, G. Taylor, Yahweh and the Sun: Biblical and Archaeological Evidence for Sun Worship in Ancient Israel (JSOTS 111; Sheffield: JSOT Press, 1993). Similarly, it is apparent that fragments in the Hebrew scriptures imply that Yahweh had been a storm god. See R. Müller, Jahwe als Wettergott. Studien zur althebräischen Kultlyrik anhand ausgewählter Psalmen (BZAW 387; Berlin: de Gruyter, 2008). See, for example, his discussion concerning the following psalms: Ps 18:4-20; 29; 65:7-14; 77:17-20; 97; 104.

24 Because Israelites were dispersed to different parts of the Near East, there probably emerged various ideological paradigms.

25 The king is mentioned only in Deut 17:14-20, but this is a later addition and, since it only restricts the activities of the king, it very probably derives from post-monarchic times. Many scholars have shown that Deut 17:14-20 was heavily edited and that even its earliest layer is dependent on texts in 1-2 Kings. See H. Dietrich Preuss, Deuteronomium (Erträge der Forschung 164, Darmstadt, 1982); P. Särkiö, Die Weisheit und Macht Salomos in der israelitischen Historiographie (PFES 60; Göttingen: Vandenhoeck \& Ruprecht, 1994), 224-228. In the entire book of Deuteronomy, the Temple of Yahweh is mentioned only in Deut 23:19. It is thus apparent that these institutions are not part of the core ideology of the book.

26 It is apparent that if Deuteronomy had been commissioned during the monarchic era, the king would be in a prominent position in the book. For discussion and arguments, 
Deuteronomy became the cornerstone of the new paradigm and it was used as a major lens to interpret reality. ${ }^{27}$ The conceptions of the transmitting community were imprinted into Deuteronomy by expansions, while the interpretative horizon of the community was strongly influenced by Deuteronomy. The community (or more probably, the communities) and the text developed together in a circle of reciprocated influence. Any challenges to Deuteronomy would have meant a challenge to the social order, and so the transmitting communities had an interest in preserving it as well as in showing that its conceptions are ancient and of divine origin. Omissions and rewritings would have been rare as long as the text was transmitted in a context of ideological continuity. In other words, one should expect radical editorial processes of most texts in the paradigm shift occasioned by the events of 586 B.C.E., while more conservative ones set in when Deuteronomy was transmitted within the Deuteronomistic movement of postmonarchic times.

The rebuilding of the temple created an entirely new ideological context, and as a consequence of this paradigm shift, more priestly- and templeoriented editorial changes, revisions, and new literary composition were created, many of which also became part of the Hebrew Bible. While Deuteronomy (and the Covenant Code) was poorly suited to a situation with an existing temple cult, thoroughly revised law texts, such as the Holiness Code, were created. Eventually the whole Pentateuch was flooded with sections that were better suited to Second Temple times when the temple and the priests had an entirely different position in the society in comparison with the preceding temple-less time.

Chronicles provides another example of a radical revision of older texts caused by the paradigm shift of the rebuilding of the temple. While the book of Kings (and many other texts the Chronicler used as sources) is largely based on a templeless time, Chronicles rewrites past history from the perspective of the temple and its priests. The book of Kings gives a rather gloomy picture of the temple, for it was repeatedly the place of an illegitimate cult, and the sins committed there were eventually the main reason for the collapse of the kingdom. Similarly, the temple priests only play a limited

see J. Pakkala, “The Date of the Oldest Edition of Deuteronomy," ZAW 121 (2009): 388401. For criticism of this position, see N. MacDonald, "Issues in the Dating of Deuteronomy: A Response to Juha Pakkala," ZAW 122 (2010): 431-435; see also my response to MacDonald's response in J. Pakkala "The Dating of Deuteronomy. A Response to Nathan MacDonald," ZAW 123 (2011): 431-436.

27 Clearly, this does not necessarily apply to all contexts and traditions that are derived from ancient Judah and Israel, but Deuteronomy seems to have become the cornerstone of traditions that had a major impact on the emergence of Judaism. 
role in Kings, because the temple probably did not exist during the time of writing. It is thus apparent that the scribes behind Kings were not particularly close to the temple and its priesthood. While this position was adequate during the time when the temple lay in ruins, its reconstruction created a new situation. The temple cult and priesthood had to be taken more comprehensively into consideration in any description of the history of Israel. Consequently, Kings became outdated for circles close to and connected to the temple, while Chronicles provided a version that better corresponded to the new ideological paradigm.

The process of adaptation to a new paradigm may not always be immediate. The religious censoring of Samuel and Kings is a case in point. ${ }^{28}$ It is apparent that, before the complete freezing of the text, several successive editors were offended by and thus corrected the perceived erroneous conceptions of the older text. The ancient Israelite and now unorthodox conceptions were thus gradually made to correspond to the new ideological paradigm of Second Temple Judaism. Censoring continued until almost all of those sections of the older texts that were in conflict with the new paradigm had been removed. ${ }^{29}$

It should also be noted that radical revision is not the only strategy for surviving a paradigm shift. A community may also resist changes even if the environment changes. Such a conservative stand usually necessitates turning inwards and actively resisting outward influences. Such a strategy may be successful, in some cases and at least for a limited period of time, but if the environment has permanently changed, it is unlikely that it will be a viable solution to deal with change. In concrete terms, the ancient Israelite religious conceptions do not seem to have survived in any community. Even if some circles might have preserved ancient conceptions for some time hoping for

28 Evidence for religious censoring in Samuel and Kings may be found, for example, in the following passages: 1 Sam 1:9, 14, 24-25; 2:11; 7:6; 2 Sam 5:8, 21, 24; 6:6-7; 7:11, 15,$16 ; 15: 8,25$; 1 Kgs $8: 12-13 ; 16: 32$; 2 Kgs 10:23; 11:12-13; 12:10; $18: 34 ; 23: 11$. The evidence is primarily text-critical in nature, although in some cases the parallel passage in Chronicles reveals that the source text was censored after the Chronicler had used Kings as the source text. Many other analogous examples can be found in other parts of the Hebrew scriptures as well.

29 According to A. Aejmelaeus, "David's Three Choices: Textual and Literary Development in 2 Samuel 24," in Changes in Scripture (ed. H. von Weissenberg et al.; BZAW 419; Berlin: de Gruyter, 2011), 137-151, the book of Samuel had to be purged of unorthodox conceptions before it could be accepted as part of the canon. The same may be true of the book of Kings. See A. Schenker, "The Septuagint in the Text History of 1-2 Kings," in The Book of Kings. Sources, Composition Historiography and Reception (ed. A. Lemaire and B. Halpern; Leiden: Brill, 2010), 3-17, here esp. p. 13. 
things to return to what they had been, the cult of the storm or solar god with an image in the temple never came back after 586 B.C.E. The texts of the monarchic period mainly survived as fragments and in a radically transformed form in poetic and law texts that had, however, already abandoned the old paradigm of the monarchic times.

Deuteronomy was originally a rather radical enterprise, as it introduced the entirely new concept of making the law the center of the new religion. ${ }^{30}$ It also portrays a religion that is not fully dependent on the temple. Especially with the nomistic additions, Deuteronomy places much more weight on the observance of the law. With the rebuilding of the temple, Deuteronomy may have been in danger of becoming outdated, and therefore it is not surprising that it was challenged by the Holiness Code and other more temple-oriented parts of the Pentateuch. However, several circles seem to have transmitted and preserved the book without adapting to the new circumstances, and in the end this strategy was successful. Partly, the success may be due to its merger with the more priestly sections of the Pentateuch - the combined composition was accommodated to various contexts and groups - but the creation of the Temple Scroll shows that not all were content. On the other hand, the new situation created by the destruction of the Second Temple in 70 C.E. made Deuteronomy centrally relevant again, as the more templeoriented parts of the Pentateuch lost part of their relevance.

\section{Theories of Natural Evolution}

In search of a model for understanding strategies of adaptation to paradigms and paradigm shifts, the theories of natural evolution provide fruitful ideas. According to the traditional theory, the so-called phyletic gradualism, the evolution of species is gradual; new species are created by continuous and constant but slow changes by adaptations to changed circumstances. ${ }^{31}$ The main problem with this theory has been the lack of proof for the gradual and small changes in the fossil record. If changes are always gradual, one would expect to find abundant evidence for them in all periods of adaptation to a new circumstance. ${ }^{32}$

30 This idea has been suggested by many since Wellhausen.

31 C. Darwin, On the Origin of Species (London: John Murray, 1859), passim, and many following him.

32 Darwin, Origin of Species, 342, assumed that this is due to the "extremely imperfect" geological record that is available, although recent discoveries suggest that there is yet more to be learned. 
Phyletic gradualism was challenged in the 1970s by another theory of evolution, the so-called punctuated equilibrium. ${ }^{33}$ According to this theory, the infrequent changes documented in the fossil record imply that evolutionary changes must be very rare. The theory thus argues that most of the time little or no evolutionary change took place, the regular state of species being stasis within an environmental equilibrium. This would explain the scarcity of evidence for evolutionary change observed in the fossil record. Small changes could take place during the periods of stasis but this usually does not lead to the creation of new species, because equilibrium does not give the impetus for creating something substantially new. Since the species are already in balance with their environment and have reached an ideal genetic makeup for that environment, most mutations would not be beneficial.

The theory of punctuated equilibrium assumes that the most substantial evolutionary development takes place during infrequent and exceptional circumstances when the development is rapid. Substantial changes in environment, such as geological catastrophes, would be such circumstances and would drive the species to adapt fast, for it is a matter of life and death. A species that does not adapt fast enough would be in danger of being replaced by others that were more adaptable to the changed environment. When one looks at the whole prehistory of a species, its evolution can be divided into two alternating and distinct periods: long periods of small change within equilibria and short periods of rapid change that punctuate the equilibria.

Although models of natural evolution are clearly not fully applicable to texts, there are evident analogies. As in the theory of punctuated equilibrium, the development within a paradigm by using mainly conservative techniques of editing has been punctuated by periods of entirely different editorial processes. Most of the development of the texts took place within a paradigm where a radical revision would not be a successful strategy. There is a high likelihood that a radically revised text would have been rejected as it would have been in conflict with the existing order. ${ }^{34}$ Moreover, there would have been little need or incentive for radical revisions when the environment did not change radically. However, rapid changes were necessary at some stages where the environment of transmission suddenly changed radi-

33 N. Eldredge and S. Jay Gould, "Punctuated Equilibria: An Alternative to Phyletic Gradualism," in Models in Paleobiology (ed. T. Schopf; San Francisco: Freeman, Cooper \& Co, 1972), 82-115.

34 This does not exclude the possibility that a splinter group revises a set of authoritative texts in a relatively stable environment. Nevertheless, it is probable (for a variety of reasons) that the environment of the splinter group is fundamentally changed and this development goes hand in hand with the revision of the texts. 
cally. Without rapid changes in such situations, the texts would not have kept up with the environment and would thus have risked becoming unviable, irrelevant, and subject to being forgotten. Those texts that were transmitted further were successful in adapting to the changed environments and had better chance of remaining relevant. As in natural evolution, rapid adaptation is one of the most successful strategies for survival, and therefore textual traditions that adapted quickly would be well represented among those texts that were preserved and survived through the centuries. Because there have been many radical changes in the environment, it is likely that most Hebrew scriptures were edited by using radical techniques at some stages in the course of their literary history. This contradicts the assumption in redaction criticism that no radical techniques were used in the entire history of the text. By the same token, the same texts were even more probably transmitted by using conservative methods in other periods of their transmission.

\section{Summary}

Documented evidence is essential when we seek to understand how the Hebrew scriptures were edited. In cases where such evidence is not available, some substitute, such as inductive reasoning and analogy from cases where it does exist, must be found. Analogy and inductive reasoning based on a limited set of evidence suggests that most texts of the Hebrew scriptures were constantly updated by editing. Since the editors did not want to undermine the existing order, they sought to preserve the stasis between the texts and the ideological paradigm in which they were transmitted. For that reason, most of the editorial changes within an ideological paradigm were expansions that could be seen as clarifications, interpretations, and explanations of the older text. If the changes in the environment of transmission were gradual enough, an ideological paradigm could be preserved. This is reflected in the texts by conservative editorial techniques that did not challenge the older text. In most cases, this was the preferred way to deal with changes in the environment.

This transmission within a paradigm by using conservative editorial techniques was occasionally punctuated by stages of radical revision. This was caused by a paradigm shift that fundamentally altered the environment of transmission. The rapidity of change meant that the ideological paradigm was shaken or collapsed. Gradual and conservative changes in the texts would not have been able to maintain the relevance of the texts in the new ideological paradigm. An ideological paradigm shift drove the editors to 
seek unconventional methods such as omissions, rewritings, and radical revisions of the older authoritative texts.

On account of several fundamental socio-political changes in the history of Israel/Judah and Judaism, it is probable that radical revisions affected most texts of the Hebrew scriptures at some stages of their transmission. Because of competition between different strategies, those that adapted quickly through radical changes were often favored in fundamentally altered circumstances, and would thus be well represented in the Hebrew scriptures. Nonetheless, although rapid adaptability is a successful strategy for survival and the documented evidence suggests that it was a rather common strategy in the transmission of the Hebrew scriptures, one should not exclude the possibility that other strategies in times of great change could also be successful.

It is necessary to stress that the observations and conclusions made in this paper may not explain all the data. The development of ancient texts was certainly a very complicated process, but to interpret the alternation that can be observed in the documented evidence through paradigms and paradigm shifts makes it easier to understand some of the development. For example, individual creativity would be more difficult to explain by the present model, which mainly seeks to relate texts to their socio-historical environment. Nevertheless, it is debatable how much freedom individual scribes would have had to alter the holy texts of a community. It is probable that in most cases the scribes were closely tied to their socio-historical context and to the changes that took place in it. Although they may not always explain all the stages in the development of the texts, categorization and abstraction may still be very helpful in understanding ancient developments.

Future redaction critical investigations of the prehistory of texts should take into account the possibility that radical editorial techniques, such as omission and rewriting, took place in the transmission of the texts. This means a revision of the method. On account of the observations made in this paper, the method should try to identify possible ideological paradigm shifts in the redactional layers that it identifies. If a paradigm shift can be identified, there is a good possibility that the older text was not always fully preserved.

Juha Pakkala

Lecturer of Biblical Exegesis and Biblical Hebrew

University of Helsinki

Department of Theology

P.O. Box 4 (Vuorikatu 3)

00014 University of Helsinki

Finland

juha.pakkala@helsinki.fit 